\title{
The Influence of Exchange Rates on
} Inflation, Interest Rates and the Composite Stock Price Index: Indonesia 2015 - 2018

\author{
Suhadak $^{1}$ and Amanda Dwi Suciany ${ }^{2}$
}

\begin{abstract}
As part of economic development, investment has become a very important part of every country in the world to increase their national income. Investment, exchange rate, inflation, the interest rate is one of many components which can be used to measure the economic condition in developing countries such as Indonesia. When Indonesia's rupiah is weakening towards USD, then country cash flow will increase towards goods services, this condition will affect inflation. Therefore, when inflation decreases, ${ }^{3}$ the government tends to take monetary policy measures to increase the interest rate in order to stabilize inflation. This phenomenon will affect economic conditions. The changes in macroeconomic variables can be indicated; each of these macroeconomic variables influences the others. This research is explanatory research with a quantitative approach. The data used is secondary data and obtained from Bank of Indonesia and Indonesia Stock Exchange. The sample in this research used a saturated sample. In order to analyze the data, this research used descriptive statistic, classical assumption test, linear regression and also path analysis. The results of this study shows that exchange rate and inflation has positive and insignificant influence towards Composite Stock Price Index, Interest rate has negative and significant influence towards Composite Stock Price Index, Exchange rate has no influence towards interest rate, inflation has positive and significant influence towards interest rate, exchange rate has negative and significantly influence inflation and interest rate has positive and significant influence towards inflation.
\end{abstract}

JEL classification: E43, E31, G15

Keyword: Indonesia, Exchange Rate, Inflation, Interest Rate, Composite Stock Price Index

\footnotetext{
${ }^{1}$ Faculty of Administrative Science, Universitas Brawijaya

${ }^{2}$ Undergraduate Student of the Faculty of Administrative Science, Universitas Brawijaya

${ }^{3}$ or becomes deflation
} 


\section{INTRODUCTION}

Changes in stock prices are influenced by several factors. According to Samsul on Widyastuti (2017:35) these are seven factors: (1) The Gross domestic product, (2) inflation, (3) the unemployment rate, (4) the interest rate, (5) the exchange rate, (6) the current account, (7) the budget deficit. Based on this statement the factors that influence changes in stock price are (1) the exchange rate, (2) the inflation, and (3) the interest rate. The exchange rate, inflation and interest rate are frequently used as referenced in macroeconomics.

Payment instrument that can be universally accepted is needed. The financial market is a term of any marketplace where trading of securities such as equities, bonds, currencies, derivative securities are offered. For investor and also firm who engaged in international activity, they will transfer money back and forth regularly, they need an exchange transaction between their home currencies to other currencies. According to Dornbusch cited in Widyastuti, (2017:36) "The exchange rate is the price of a country's currency is exchanged for another country's currency.". Therefore, the United States's currency is one of currency that is used as a payment instrument for Indonesia's international trade.

The stability of the United State's currency against the Indonesian Rupiah give an impact for Indonesia economy. The weakening of domestic currency will affect increasing prices of goods and services. Otherwise, if the Indonesian Rupiah stabilises, it will increase people's capability to invest and purchase through goods or services. The fluctuation in the rupiah value against the USD may have an impact on inflation, interest rate and changes in stocks prices of companies listed on the Stock Exchange. This is related to the majority of companies listed on the stock exchange have foreign debt in foreign currencies, especially the USD. Moreover, there are many foreign investors, who invested in Indonesia, and this condition becomes the reason why exchange and investment are related. This condition also affected the money circulating in the society and various parties to take financial strategy.

According to Wahyudi, Asdar and Nohong (2017:135) "The exchange rate is a variable that many foreign investors pay attention to. Exchange rates traded in the stock market will have a substitution effect with the stock market. When the rupiah depreciates holding the dollar will be more profitable for investors."

Figure 1 explains about the United States currency exchange fluctuation period of 2015 (January December). From the data above the highest value of US\$ in IDR was happened in September amount of Rp.14.396,-per US\$. The lowest value of US\$ towards the Indonesian Rupiah (IDR) in the amount of Rp.12.579,- happened in January 2015. In addition, Indonesia followed free floating currency policies to measure currency control. The weakening of rupiah against the USD (depreciation) will increase the cost of raw material for production activity. The decreasing of company's profit will cause dividends that will be received by shareholders. Especially for companies that are import oriented and used the USD to purchase their transaction. 
Figure 1 The Exchange Rate of Dollar to IDR in 2015 (January-December)

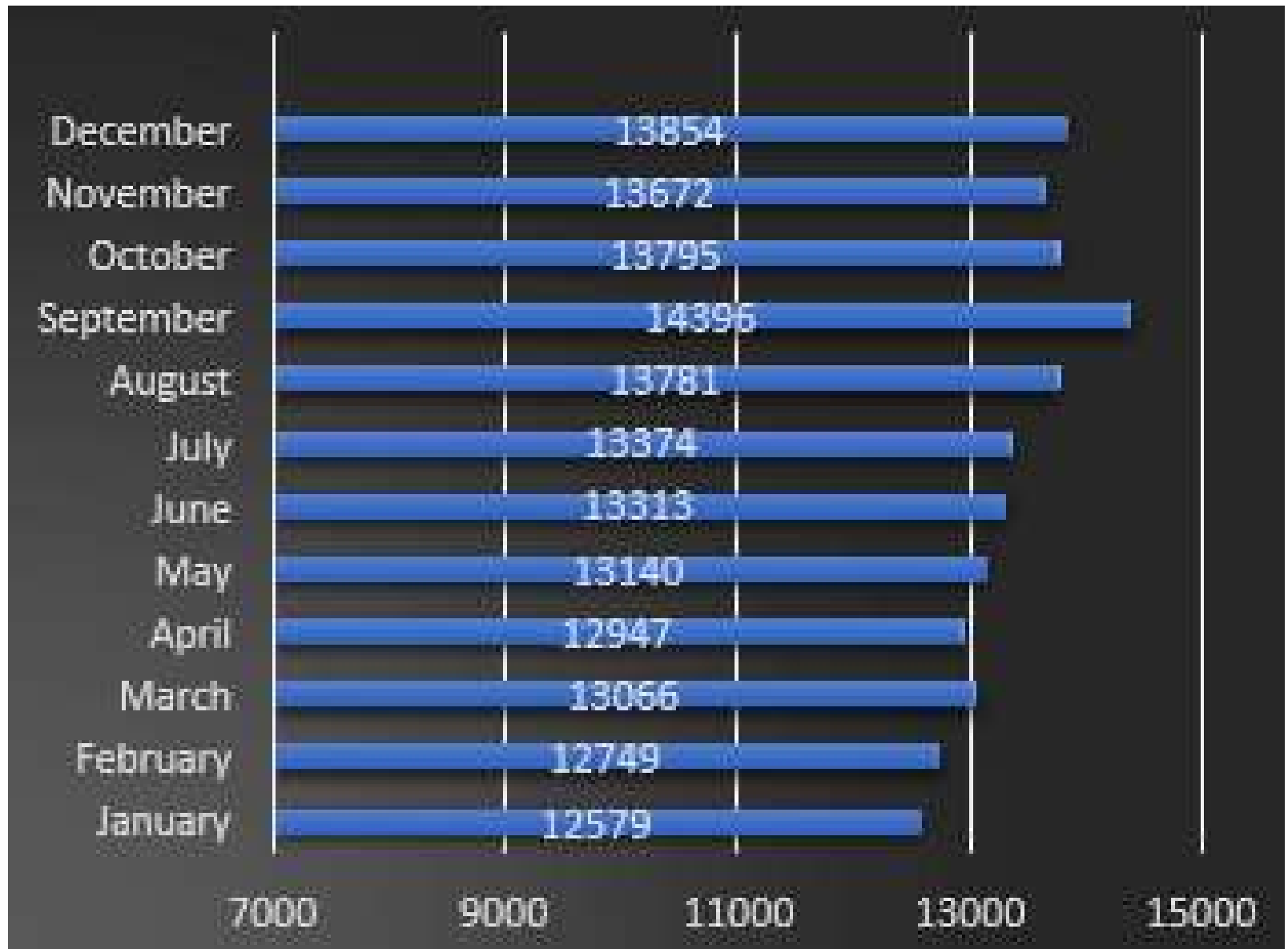

Source: Bank of Indonesia Official Website, 2018

Other macroeconomic factors that affected by the United States's currency exchange rate are inflation that will influence the Composite Stock Price Index. According to Nofiatin (2013:216)," when inflation occurs it will caused the increases price of goods and services, and decrease people ability to purchase". When the demand of the USD relatively increases to it is supply, this excess growth in the money supply will cause inflation in Indonesia. In conclusion, the inflation rate is influencing by supply and demand of currency in a country. Moreover, inflation was seen by the investors as a benchmark of economy condition. The growth of inflation rate will affect the investor are less attracts to invest their capital. The outcome of inflation is it will increase the prices of goods and if the production cost increasing higher than the price of a product, this condition will affect the company's profit and influencing the dividend that will be obtained by the investors.

Other factors which influence by the exchange rate are the interest rate. The interest rate in a country has a very important role, especially in a country economic growth. Interest rate is loaning cost or revenue from crediting. According to Murdifin and Mangkona (2017:31), "The interest rate is the cost to borrow money, measured in American dollar per year for every dollar borrowed". Interest rate can be used by an investor to forecast the ability in the financial market. The higher the rate of interest rate offered by banks, the greater the tendency to encourage more people to save their money. 
Inflation and interest rate are often linked and frequently used in macroeconomics. When inflation occurs, the governments tend to increase the interest rate. The purpose of this policy is to encourage the community to save their money in the banks.

Table 1 Indonesia's Inflation Rate and Interest Rate in 2017

\begin{tabular}{|l|l|l|}
\hline Months & Inflation Rate & Interest rate \\
\hline January & $3.49 \%$ & $4.75 \%$ \\
\hline February & $3.83 \%$ & $4.75 \%$ \\
\hline March & $3.61 \%$ & $4.75 \%$ \\
\hline April & $4.17 \%$ & $4.75 \%$ \\
\hline May & $4.33 \%$ & $4.75 \%$ \\
\hline June & $4.37 \%$ & $4.75 \%$ \\
\hline July & $3.88 \%$ & $4.75 \%$ \\
\hline August & $3.82 \%$ & $4.50 \%$ \\
\hline September & $3.72 \%$ & $4.25 \%$ \\
\hline October & $3.58 \%$ & $4.25 \%$ \\
\hline November & $3.30 \%$ & $4.25 \%$ \\
\hline December & $3.61 \%$ & $4.25 \%$ \\
\hline
\end{tabular}

\section{Source: Bank of Indonesia Official Website, 2018}

Table 1 shows the rates of inflation and interest in Indonesia in 2017. As this table shows, inflation in Indonesia fluctuated from January to December and the highest inflation rate happened in the month of June and the lowest inflation happened in the month of April. Meanwhile, Table 1 also showed the fluctuation of interest rates from January to December. The interest rate in 2017 was stable from January to July in the amount of $4.75 \%$. As mentioned in the statement above, inflation and interest rates are often linked and frequently used in macroeconomics. When inflation occurs, the governments tend to increase the interest rate. The purpose of this policy is to encourage the community to save their money in the banks. Generally, if interest rate decrease, more people obtain cash by borrowing money from the banks. The outcome is, the consumers has more cash to spend, making the economy develop and increase inflation.

The existence of a capital market in a country can be used to improve economic growth. The capital market also can be the option for private and governments as a funding alternative. There are a few instruments in the capital market, one of them is stock. The stock is the most popular instrument in the capital market and also can be the option for investors to invest their capital or excess fund. Stock is an evidence of the capital participation of a person or business entity, by enclosing the capital that parties have a claim on company's income and canattend the general meeting of shareholders.

In the discussion of stocks, there is a stock index term. The stock index can be used by an investor or prospective investors to get information concerning the develompent of the stock. In Indonesia stock movement can be observed through the stock index. There is a few types of stock index in Indonesia, one of them is Composite Stock Price Index or Index Harga Saham Gabungan. The 
composite stock price index is a type of stock price index which be appointed to measure the performance of all the stocks which are listed in the Indonesia Stock Exchange. Composite Stock Price Index according to Downes and Godman on Widyastuti (2017:35), Composite Stock Price index is "The index is a statistical composite that measure changes in the economy or financial markets". Composite Stock Price Index is considered as a basic of analysis that is used the most by analysts to discover and observe the stock condition in Indonesian capital market. This can be proven because Composite Stock Price Index is intensively observing the stock movement in the capital market whether it is common stock or preferred stock, so that the CSPI analysis should observing and considering the numbers that is in market capitalization.

Based on the explanation above, the exchange rate gives has an impact in economic sectors such as inflation, interest rate and the Composite Stock Price Index. When the Indonesian rupiah is weakening towards USD, then country cash flow will increase towards goods and services, this condition will affect inflation. Therefore, when the inflation rate decreases the governments would take monetary policy to increase the interest rate in order to stabilize inflation rate. This phenomenon will affect the economic condition. The changes in macroeconomic variables can indicated, each of this macroeconomics variable are influencing each other and have a strong enough influence on the performance of the Indonesia Capital Market. Especially, the Composite Stock Price Index.

\section{LITERATURE REVIEW}

\section{Exchange Rate}

International trade will encourage exchange between two or more different currencies. The exchange rate is one of the basic economic tools that are used to correct a number of economic misalignments facing a nation. However, for this result to sustain economic growth and development stability must be maintained in exchange rate. According to Joesoef on Rohmanda, Suhadak and Topowijono (2014:2) "an exchange rate is the amount of a currency which can be converted on a unit of another currency". According to Murdifin and Mangkona (2017:30) "Foreign currency exchange rate is the price of a country's currency against the currency of other countries. Foreign exchange rate determined in the foreign exchange market, the market where a variety of different currencies traded". As indicated by Mankiw (2009: 135) "The exchange rate between two countries is the price at which residents of those countries trade with each other".

The exchange is a payment instrument for international transactions towards economic activities and as current domestic currency price towards foreign currencies price. The weakening in a currency value indicates the depreciation, vice versa the strengthening in currency value can be defined as appreciation. However, the exchange rate is nothing more than a value of a foreign currency against domestic currency. If foreign currency visualized like general goods, it is value will be determined by supply and demand of a currency. According to Noor (2014:236) "Exchange rate is the exchange value between a currency against another currency". The exchange rate can be divided into two, namely, (1) hard currency, hard currency is a currency which originates from a developed country such as Yen, Dollar, Euro. (2) soft currency, soft currency is a currency that is rarely used as a payment instrument, and the currency value and soft currency often experience depreciation. 


\section{Inflation}

According to Karim (2015:135) "Generally, inflation means an increase in the general price level of goods and commodities or services for a certain period of time.". In the accordance to Hasyim (2016:186)" Inflation can results in a number of adverse consequences for individuals, communities and overall economic activities. That's why government made various efforts by looking for ways to overcome inflation.". Meanwhile, according to Rahardja and Manurung on Rohmanda et al (2014:2-3) put forward in the definition of inflation, there are three important components which have to be addressed, "Firstly, there is a tendency of rising price, even a certain of time there is a depreciation or appreciation compared to the previous event but still shows a tendency to increase. Secondly, the rising price that occurs tends to be general, it is means the increase in price is not only suffered by just one or few commodities. And third, the increase of price that continuously occurs, which is mean it is not happening in a certain of time.".

According to the inflation rating scale, Inflation can be classified into 3 categories. According to Samuelson on Karim (2015:137-138) such as follow as:
a. Moderate Inflation
b. Galloping Inflation
c. Hyperinflation

\section{Investment}

According to Hartono (2015:5) "Investment is current consumption delays to be put into productive active for a certain period of time.". They are not classified as operating activities since the relate only indirectly to the central, ongoing operations ofentity.".Investment can be defined as "The current commitment of dollar for a period of time to derive future payment that will compensate the investor for (1) the time fund committed, (2) the expected rate of inflation,(3) the uncertainty of the future payment.". (Relly and Brown on Fahmi,2014:2).

To achieve effectiveness and efficiency in decisions, it is necessary to assert the expected goals. Similarly, in the field of investment, investors must set goals to be achieved. According to Fahmi (2014:264), there are several objectives in investment:

1) To create a sustainability in the investment.

2) To gain maximum profit or expected profit.

3) To create prosperity for shareholders.

4) To contribute to the nation's development.

According to Fahmi (2014:265) basically investment known as two form, such as follow:

1) Real Investment

2) Financial Investment

As investors or potential investors, those who will invest and want to invest, they can choose and decide what type of financial assets to be chosen. In this case there are two types of investments that investors can choose .According to Hartono (2015:7-10), such as follow:

1) Direct Investment

2) Indirect Investment 


\section{Interest Rate}

"Interest rate is the payment made for the use of money. The interest rate is the amount of interest to be paid per unit of time. In other words, the public must pay to borrow money opportunities."(Murdifin and Mangkona, 2017:31). In the accordance of Agustina and Sunoryo cited in Widyastuti (2017:36) " the rate of interest of the financial sectors is often used as a guide or reference for investors to assess the abillity of financial markets to generate optimal profits is the interest rate of Bank Indonesia Certificates (SBI).".

In the accordance of Samuelson and Nordhaus on Murdifin and Mangkona (2017:31) "the interest rate is the cost to borrow money, measured in American dollar per year for every dollar borrowed". According to Murdifin and Mangkona (2017:31) interest rate can be divided as follows:

the nominal interest rate is the interest rate in the value of money. The rate is a value that can be read in general. Interest rates showed a number of rupiah for every single rupiah invested. The real interest rate is the interest that has undergone a correction due to inflation and is defined as the nominal interest rate minus the inflation rate. The interest rate is expressed as a rate return/income provided by Bank Indonesia to investors in the auction of SBI (Bank Indonesia Certificate) term of one year or commonly known as Bank Indonesia Certificate.

\section{Composite Stock Price Index}

An index is needed as an indicator to observe price movements of securities. In Indonesia capital market, there is an index which describes the entire movement of stock listed in Indonesian Stock Exchange, this index is usually called as Composite Stock Price index. This index is used by the researcher as a benchmark to observe investment condition in Indonesia. In accordance of Rahayu on Widyastuti (2017:36) " This index cover all the common stock price movement and prefferent stock listed in the Indonesia Stock Exchange"

Composite Stock Price Index is a value to measure the performance of all companies stock's listed in the Indonesia stock exchange. Composite Stock Price Index is considered as a basic of analysis that is used the most by analysts to discover and observe the stock condition in Indonesian capital market. This can be proven because Composite Stock Price Index is intensively observing the stock movement in the capital market whether it is common stock or preferred stock, so that the Composite Stock Price Index analysis should observing and considering the numbers that is in market capitalization. CSPI was introduced to the world for the first time at $1^{\text {st }}$ April 1983 by using the baseline at $10^{\text {th }}$ August 1982 .

Composite Stock Price index contains historical information about the movement of composite stock prices and also can identify the economic condition of a country. Composite Stock Price Index observe insensitively the movement in the stock market, wether it is common stock or prefferent stock, so the analysis must notice and consider the number contained in market capitalization". To calculated Composite Stock Price Index as follows: 


\section{CSPI $=\left(\right.$ Market Value $_{t}:$ Basic Value $) \times 100$}

Figure 2 : The Calculation of CSPI

Source: Hartono (2015:153)

Where:

CSPI: Composite Stock Price index

Market Value $_{\mathrm{t}}$ : the weighted average market value (the number of sheets listed on the exchange multiplied by the market price per sheet) of common stock and preferred stock on day-t

Basic Value: same as the market value but it was started at $10^{\text {th }}$ August 1982

Composite Stock Price Index can be defined as an index which describes the entire movement of stock listed in Indonesia Stock Exchange. This index commonly used by investors to observe market's condition and also the development of capital market in a country can be seen from high number of Composite Stock Price Index. Thus, the Composite Stock Price Index is a reflection of capital market activity.

\section{Hypothesis}

$\mathrm{H}_{1}$ : The exchange rate, inflation and interest rate have significant influence partially and simultaneously on the Composite Stock Price Index.

$\mathrm{H}_{2}$ : The exchange rate and inflation have significant influence partially and simultaneously on the interest rate.

$\mathrm{H}_{3}$ : The exchange rate and interest rate have significant influence partially and simultaneously on the inflation

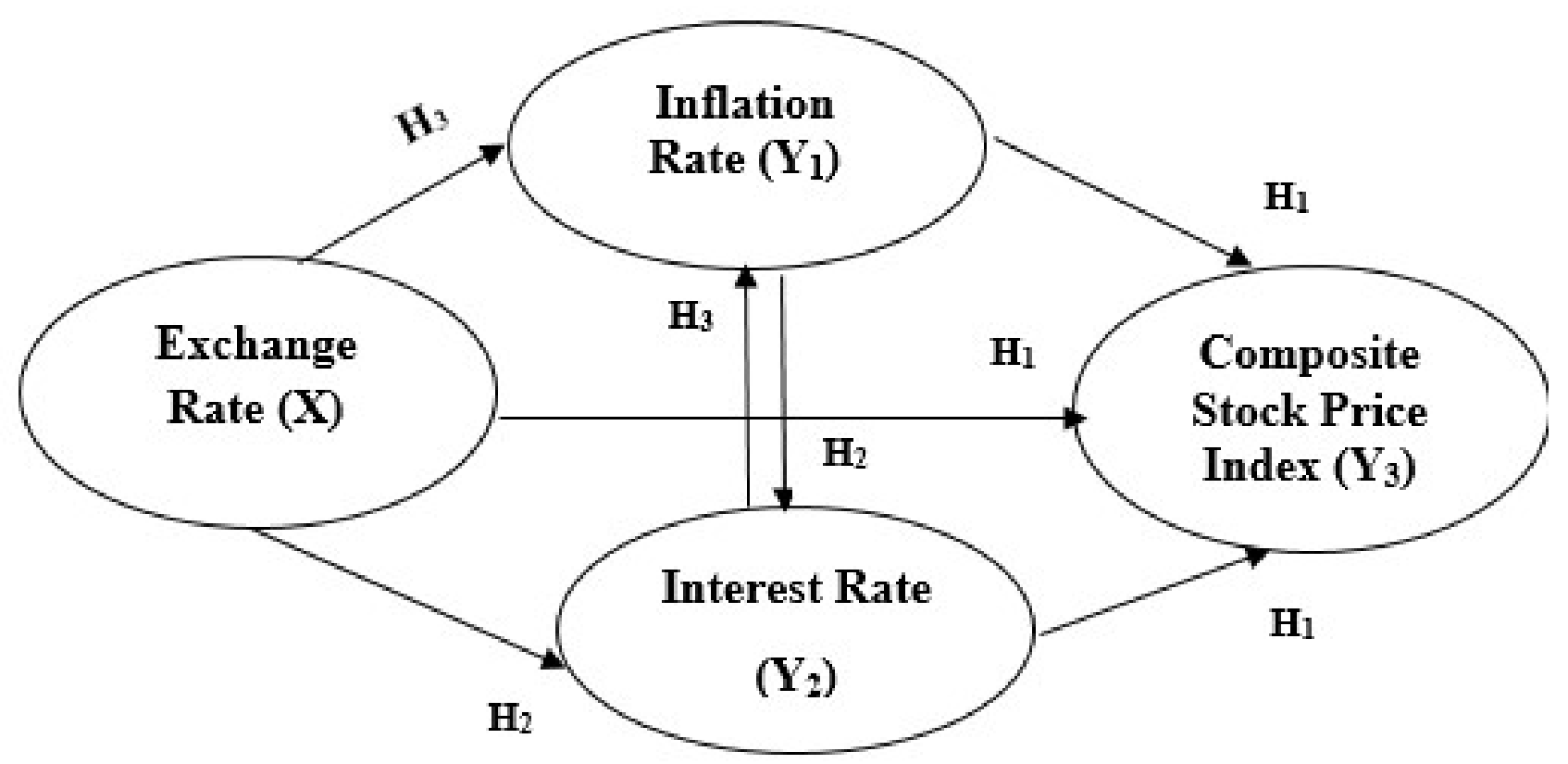


Figure 2 Multiple Linear Hypothesis model RESEARCH METHOD

This research method is explanatory research with a quantitative approach. Explanatory research aims to identify any causal links between the factors (variables) that pertain to the research problem. The location of this research were at the official website of Bank Indonesia to collected exchange rate, inflation rate and interest rate data. The research were also conducted in the official website of Indonesia Stock Exchange to collected the composite stock price index date data. The researcher chooses these location because in Indonesia Stock Exchange website or at (www.idx.co.id) and Bank Indonesia website or at (www.bi.go.id) provide accurate data for this research. This study uses secondary data in the form of time series data taken in the prdiode of January 2015 until October 2018. This research consist of monthly observation of each variable. Therefore, the total population of this research is 46 data points.

\section{RESEARCH RESULTS AND DISCUSSION}

Table 3 The Summary of Direct Effect, Indirect Effect and Total Effect

\begin{tabular}{|c|c|c|c|c|c|}
\hline \multirow{2}{*}{ No } & \multirow{2}{*}{$\begin{array}{l}\text { The Relation Between } \\
\text { Variable }\end{array}$} & \multirow{2}{*}{$\begin{array}{l}\text { Variable } \\
\text { Moderator }\end{array}$} & \multicolumn{2}{|r|}{ Effect } & \multirow{2}{*}{ Total Effect } \\
\hline & & & Direct & Indirect & \\
\hline \multirow[t]{2}{*}{1.} & & & & & \\
\hline & $\begin{array}{l}\text { Exchange Rate } \\
\text { Towards Composite } \\
\text { Stock Price Index } \\
\text { Through Inflation }\end{array}$ & Inflation & 0.254 & $\begin{array}{r}-0.13277 \\
(-0.781 \times 0.170)\end{array}$ & $\begin{array}{c}0,12123 \\
\text { Insignificant }\end{array}$ \\
\hline 2. & $\begin{array}{l}\text { Exchange Rate } \\
\text { towards Composite } \\
\text { Stock Price Index } \\
\text { Through Interest Rate }\end{array}$ & $\begin{array}{l}\text { Interest } \\
\text { rate }\end{array}$ & 0.254 & $\begin{array}{c}-0,408588 \\
(0.431) \text { X }(-0.948)\end{array}$ & $\begin{array}{c}-0,154588 \\
\text { Insignificant }\end{array}$ \\
\hline 3. & $\begin{array}{l}\text { Inflation towards } \\
\text { Composite Stock Price } \\
\text { Index through } \\
\text { interest rate. }\end{array}$ & $\begin{array}{l}\text { Interest } \\
\text { rate }\end{array}$ & 0.170 & $\begin{array}{c}0,659808 \\
(0,696) \times(-0,948)\end{array}$ & $\begin{array}{c}-0,489808 \\
\text { Insignificant }\end{array}$ \\
\hline
\end{tabular}




\begin{tabular}{|r|l|c|c|c|c|}
\hline 4. & & - & 0,13311 & \\
& $\begin{array}{l}\text { Interest Rate Towards } \\
\text { Composite Stock Price } \\
\text { Index Through } \\
\text { Inflation }\end{array}$ & Inflation & 0.948 & $(0,783) \mathrm{X}(0.170)$ & $\begin{array}{c}-0,81489 \\
\text { Significant }\end{array}$ \\
\hline 5. & $\begin{array}{l}\text { Interest } \\
\text { rate } \\
\text { Exchange Rate } \\
\text { Towards Inflation } \\
\text { through Interest Rate }\end{array}$ & 0.781 & $(0,431) \mathrm{X}(0,783)$ & $\begin{array}{c}-0,443527 \\
\text { Significant }\end{array}$ \\
\hline 6. & $\begin{array}{l}\text { Exchange Rate } \\
\text { Towards Interest Rate } \\
\text { Through Inflation }\end{array}$ & Inflation & 0,431 & $(-0,781)$ X $(0.696)$ & $-0,112576$ \\
& & & & Insignificant \\
\hline
\end{tabular}

Source: Processed by Researcher, 2019

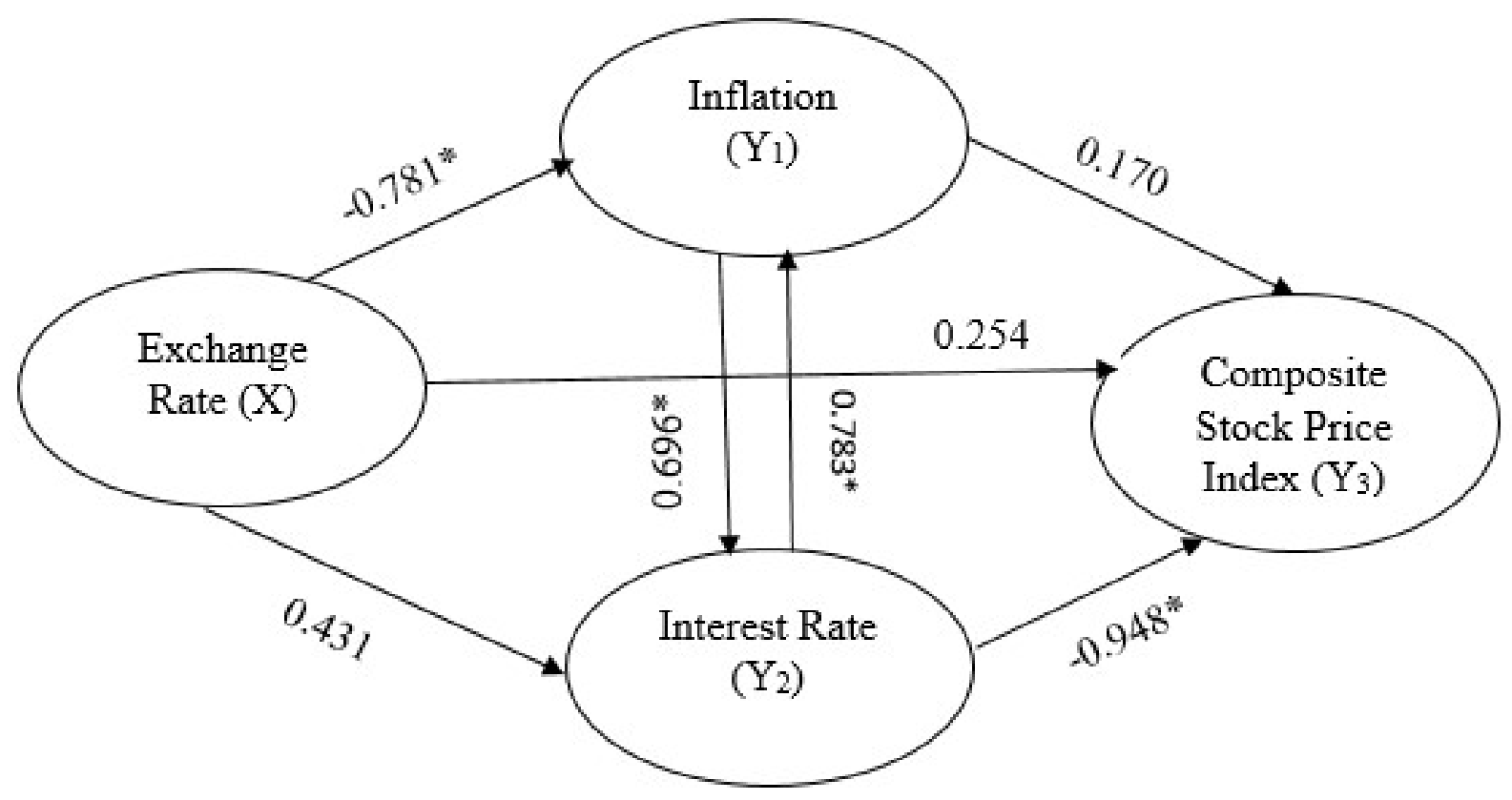

Figure 3: The Results of Path Analysis Diagram

Source : Processed by Researcher, 2019 


\section{The Influence of Exchange Rate, Inflation Rates and Interest Rates on the Composite Stock Price Index}

The influence of the exchange rate, inflation and interest rate in this research simultaneously influencing Composite Stock Price index, where the significance value is 0.000 . According to the results of $F$ test, the significance value less than 0.050 or $0.000<0.050$, the results had shows exchange rate, inflation and interest rate, simultaneously influence Composite Stock Price Index significantly. This results clarified by Harsono's (2018) research which stated that exchange rate, inflation and interest rate simultaneously has significant influence towards Composite Stock Price Index.

According Widyatusti (2017:35)," the economic crisis will have an impact on capital market activity is reflected in the decline of the stock market price is reflected in the Composite Stock Price Index".

The influence of exchange rate towards Composite Stock Price Index in this research is the significance value is 0.393 , where the significance value is greater than 0.05 or $0.393>0.05$ the results also shows the value of beta is 0.254 . According to this results, exchange rate has positive and insignificant effect towards Composite Stock Price Index. The decision of Exchange rate has no influence towards Composite Stock Price Index clarified on the result of Andriana (2015) which stated that exchange rate has positive influence but not significantly affected the stock price post initial public offering in companies listed on Indonesia's Stock Exchange. This research are not in line with Wahyudi (2017) research which stated that the exchange rate has negative and significant influence on the Composite Stock Price Index. This results also not in line with Rohmanda et al. (2014) which stated that exchange rate significantly affected sectoral index in Indonesia's Stock Exchange.

The influence of the inflation rate towards the Composite Stock Price Index shown in this research has a significance value of 0.190 , where the significance value is greater than 0.05 or $0.190>0.05$, the results also shows the value of beta is 0.170 . According to the results, it can be concluded that inflation has positive and insignificant effects towards Composite Stock Price Index. According to Putong on Harsono (2018:106) inflation of under 10\% is still can be accepted by the market, because inflation is still in the low category". This condition also based on described theory of category of inflation, one of the category is moderate inflation. The characteristic of moderate inflation is a slow increase in the price level, generally referred to 'single digit inflation'. As the level of inflation people still have desire to hold money and save their wealth in the form of money rather than in real assets. The results of inflation has no significant effect towards Composite Stock Price Index in a line with Setyawan (2018) which stated if inflation has no significant effect towards Composite Stock Price Index. In Accordance to this research concluded if investors want to invest their capital in rill sectors, investors are not considering inflation but tend to consider the company performance. Another reason is, the fluctuations in the inflation rate in the year of research were not too high, so it did not have a significant effect on the Composite Stock Price Index. This result is also in line with Harsono (2018) which stated that inflation partially has no influence on the Composite Stock Price Index. This research is not in line with Hidayat (2017) which stated that inflation does have influence towards the Composite Stock Price Index. 
The influence of interest rate towards the Composite Stock Price Index in this research is that the significance value is 0.000 , where the significance value is less than 0.05 or $0.000<0.05$ the results also shows the value of beta is $-0,948$. According to the results, the interest rate has negative and significant influence towards Composite Stock Price Index. The interest rate has influence towards Composite Stock Price Index, this implies that stock's investors observe the performance of interest rates, in order to make investment decisions. According to this study, interest rate has a negative influence towards Composite Stock Price Index, this is in accordance with the theory described, which is interest rate has negative influence towards Composite Stock Price Index, If the interest rate increases, then the investors tend to divert their fund or capital from stock investment to deposits, and give negative influence towards Composite Stock Price Index.

The decision of interest rate has influence towards Composite Stock Price Index clarified on the result of Harsono (2018) research which stats that interest rate partially give significant effect towards Composite Stock Price Index. This results also in line with Wahyudi et al (2017) which stated that BI rate has a negative and significant effect towards Composite Stock Price Index.

\section{The Influence of Exchange Rate and Inflation on Interest Rates}

The influence of exchange rate and inflation towards interest rate in this research had shows the significance value as much as 0.000 . According to the results the significance value less than 0.05 , or $0.000<0.05$, which is means that exchange rate and inflation simultaneously has significant influence towards interest rate. This results support International Effect Theory. The IFE theory stated that exchange rate movements are caused by inflation rate differential. If difference in expected inflation are the only reason for any difference in nominal interest rate then interest rate and inflation difference should be the same. The IFE theory suggests that foreign currency with relatively high interest rate will depreciate in much the same way as currency with high interest rate.

The influence of exchange rates on interest rates is coefficient value of exchange rate is that the significance value is 0.192 , where the significance value is greater than 0.05 or $0.192>0.05$ the results also shows the value of beta is 0.431 .According to the results exchange rate has positive and insignificant effect towards interest Rate. This results are not in line with Ebiringa and Anyaougu (2014) research which stated that interest rate and exchange rate has negative and insignificant effect.

The influence of inflation rate towards interest rate is the significance value is 0.000 , where the significance value is smaller than 0.05 or $0.000<0.05$ the results also shows the value of beta is 0.696. The decision is inflation has significant and positive effect towards interest rate. The decision of inflation has significant effect toward interest rate clarified by the statement of Nofiatin (2013) research which stated that the relation between inflation and interest rate happens when inflation increase, then Bank Indonesia will also increase the interest rate which aims to decrease inflation. This results is in line with Langi et al. (2014) which stated that inflation and interest rate has positive and significant effect. 


\section{The Influence of exchange rate and interest rates on inflation.}

The influence of exchange rate and interest rate towards inflation in this research had shows the significance value as much as 0.000 . According to the results the significance value less than 0.05 , or $0.000<0.05$, which is means that exchange rate and interest rate simultaneously has significant influence towards inflation. This results clarified by Langi, Masinambow and Siwu (2014) research which states that exchange rate, interest rate and money supply simultaneously has significant influence towards inflation.

The influence of exchange rate towards inflation is that the significance value is 0.023 , where the significance value is smaller than 0.05 or $0.023<0.05$ the results also shows the value of beta is 0.781 . The decision is exchange rate has negative and significant influence towards inflation. According to the relation between exchange rate and inflation described, when foreign exchange strengthen against rupiah, the price of goods and services will increase and this condition made inflation rate increase. Based on the cause of inflation, Supply inflation or cosh-push inflation, occurs caused by any developments that drive changes in rising prices. The increase in the foreign exchange rate leads to the cheaper for foreign consumers, resulting in the increases of export, total demand and price. The increase in the foreign exchange rate raises the inflation. This results is not in line with Munfarid and Akin (2017) which stated that the exchange rate in one period influence on inflation and also exchange rate affected inflation positively. This results also not support the purchasing power parity theory which stated that the appreciate of exchange rate followed the increased of inflation.

The influence of interest rate towards inflation is that the significance value is 0.000 , where the significance value is smaller than 0.05 or $0.023<0.05$ the results also shows the value of beta is 0.783 . The decision is interest rate has positive and significant effect towards inflation. Nofiatin (2013) research which stated that the relation between inflation and interest rate happens when inflation increase, then Bank Indonesia will also increase the interest rate which aims to decrease inflation. This results in line with Langi et al. (2014) which states that inflation and interest rate has positive and significant effect.

\section{CONCLUSION \& RECOMMENDATIONS}

The influence of exchange rate, inflation and interest rate towards Composite Stock Price Index: The influence of exchange rate, inflation and interest rate in this research simultaneously influence the Composite Stock Price index. These results are clarified by Harsono's (2018) research which stated that the exchange rate, inflation and interest rate simultaneously has significant influence on the Composite Stock Price Index. According Widyatusti (2017:35)," the economy crisis will have an impact on capital market activity is reflected in the decline of the stock market price is reflected in the Composite Stock Price Index.".

The influence of exchange rate towards Composite Stock Price Index in this research is the exchange rate has a positive and insignificant effect towards Composite Stock Price Index. This results clarified the result of Andriana (2015) which stated that the exchange rate has positive influence but not significantly affected the stock price post-initial public offering in companies listed on Indonesia's Stock Exchange. This research is not in line with Wahyudi (2017) research which stated that the exchange rate has a negative and significant influence on the Composite Stock 
Price Index. This results also not in line with Rohmanda et al (2014) which stated that the exchange rate significantly affected sectoral index in Indonesia's Stock Exchange.

The influence of the inflation rate towards the Composite Stock Price Index in this research is that inflation has a positive and insignificant effect towards the Composite Stock Price Index. The results of inflation have no significant effect towards Composite Stock Price Index in a line with Setyawan (2018) which stated that inflation has no significant effect towards the Composite Stock Price Index. This results also in line with Harsono (2018) which stated that inflation partially has no influence towards Composite Stock Price Index. This research is not in line with Hidayat (2017) which stated if inflation has influence towards Composite Stock Price Index.

The influence of the interest rate on the Composite Stock Price Index in this research is that interest rate has a negative and significant influence towards Composite Stock Index. The decision of interest rate has influence towards Composite Stock Price Index clarified on the result of Harsono (2018) research which stats that interest rate partially give significant effect towards Composite Stock Price Index. This results also in line with Wahyudi et al (2017) which stated that BI rate has a negative and significant effect towards Composite Stock Price Index.

The influence of exchange rate and inflation towards interest rate:

The influence of exchange rate and inflation towards interest rate in this research has shown that exchange rate and inflation simultaneously has significant influence towards interest rate. This results support International Effect Theory. The IFE theory stated that exchange rate movements are caused by inflation rate differential. If difference in expected inflation are the only reason for any difference in nominal interest rate, then interest rate and inflation difference should be the same. According to the IFE theory suggest that foreign currency with relatively high interest rate will depreciate in much the same way as currency with high interest rate.

The influence of exchange rate towards interest rate in this research had shown that exchange rate has positive and insignificant effect towards interest Rate. This results are not in line with Ebiringa and Anyaougu (2014) research which stated that interest rate and exchange rate has negative and insignificant effect.

The influence of inflation towards interest rate in this research has shown that inflation has significant and positive effect toward interest rate clarified by the statement of Nofiatin (2013) research which stated that the relation between inflation and interest rate happens when inflation increase, then Bank Indonesia will also increase the interest rate which aims to decrease inflation. This results in line with Langi et al. (2014) which stated that inflation and interest rate has positive and significant effect.

The influence of exchange rate and interest rate towards inflation:

The influence of exchange rate and interest rate towards inflation in this research had shown that exchange rate and interest rate simultaneously has significant influence towards inflation. This results clarified by Langi, Masinambow and Siwu (2014) research which states that exchange rate, interest rate and money supply simultaneously has significant influence towards inflation.

The influence of exchange rate towards inflation in research had shown that exchange rate has negative and significant influence towards inflation. This results is not in line with Munfarid and 
Akin (2017) which stated that the exchange rate in one period influence on inflation and also exchange rate affected inflation positively. This results also not support the purchasing power parity theory which stated that the appreciate of exchange rate followed the increased of inflation.

The influence of interest rate towards inflation in this research had shown that interest rate has positive and significant effect towards inflation. This results in line with Nofiatin (2013) research which stated that the relation between inflation and interest rate happens when inflation increase. This results in line with Langi et al. (2014) which states that inflation and interest rate has positive and significant effect.

\section{Recommendations and suggestions for future research}

1. Theoretical Suggestions:

a. In accordance the results of this research, in order to examines the influence of exchange rate towards inflation, interest rate and Composite Stock Price Index. The researcher expected that the further research will add other macroeconomy variable which have direct influence towards inflation, interest rate and Composite Stock Price Index.

b. Recommendation for further researcher to use other currencies exchange such as euro, yen or pound sterling, which have relation towards macroeconomic variable.

2. Practical Suggestion:

The results of this research can be taken into consideration by investors making a decision before investing their capital due to several macroeconomics factors that will be affected the Composite Stock Price Index. The results of this study can also be advisory for the government to keep abreast of the fluctuation of exchange rate, inflation rate, interest rates and the Composite Stock Price Index.

\section{REFERENCES}

Andriana, Denny 2015, Pengaruh Nilai Tukar Terhadap Harga Saham Setelah Initial Public Offering (IPO), Jurnal Riset Akuntansi dan Keuangan, Vol.3 No.3.pp, 761-767.

Ebiringa, Oferegbunam Thaddeus, Anyaogu, \& Nnneka, B 2014, Exchange Rate, Inflation and Interest Rates Relationships: An Autoregressive Distributed lag Analysis, Journal of Economic and Development Studies, Vol.2 No 2, pp.263-279.

Harsono, Ardellia Rezeki 2017, Pengaruh Inflasi, Suku Bunga dan Nilai Tukar Rupiah Terhadap Indeks Harga Saham Gabungan (Studi pada Bursa Efek Indonesia Periode 2013-2017), Journal of Business Administration, Vol 60 No 2, pp 102110 .

Fahmi, Irham 2012, Manajemen Investasi Edisi 2: Teori dan Jawaban, Salemba empat, Jakarta.

Fahmi, Irham 2015, Manajemen Keuangan Perusahaan dan Pasar Modal, Mitra Utama Media, Jakarta.

Hasyim, Ali Ibrahim 2016, Ekonomi Makro, Prenadamedia Group, Jakarta. 
Hidayat, Rahmat 2017, Pengaruh Foreign Direct Investment, Inflasi, Indeks Philippine Stock Exchange, dan Indeks Straits Times Terhadap Indeks Harga Saham Gabungan, Journal of Business Administration Brawijaya University.

Karim, Adiwarman A 2015, Ekonomi Makro Islam, PT. Raja Grafindo Persada, Jakarta.

Langi, M. T, Masinabow, V, \& Siwu, H 2014, Analisis Pengaruh Suku Bunga, Jumlah Uang Beredar,dan Tingkat Kurs Terhadap Tingakat Inflasi di Indonesia, Jurnal Berkala Ilmiah Efisiensi, 44-58.

Murdifin, I, \& Mangkona, SA 2017, Effect of Composite Stock Price Index, Exchange Rate and Interest Rate Share Price of Mining Companies Listed in Indonesia Stock Exchange, IRAInternational journal of Management and Social Science, Vol.09 issue 01, pp.27-35.

Nofiatin, Ike 2013, Hubungan Inflasi, Suku Bunga, Produk Domestik Bruto, Nilai Tukar, Jumlah Uang Beredar dan Indeks Harga Saham Gabungan”, Jurnal Aplikasi Management, Vol.11 No 2, pp 215-222.

Noor, Henry Faizal 2014, Investasi, Pengelolaan Keuangan, dan Pengembangan Ekonomi Masyarakat, Mitra Media Utama, Jakarta.

Rohmanda, D. Suhadak \& Topowijono 2014, Pengaruh Kurs Rupiah,Inflasi, dan BI Rate Terhadap Harga Saham Gabungan, Journal of Business Administration Brawijaya University, Vol 13, No 1 Agustus 2014, pp. 1-10.

Wahyudi, Rifqi Nur, Asdar, Muh, \& Nohong, Mursalim 2017, The Influence of Macroeconomic Variable Toward Jakarta Composite Index on Indonesia Stock exchange, Jurnal Bisnis, Manajemen dan Informatika, pp.131-147.

Widyastuti, Maria 2017, Analysis of Effect Inflation, Interest rate, Rupiah Exchange Rate Towards Composite Stock Price Index with The Gross Domestic Product as Moderation Variable in the Indonesia Stock Exchange, The International Journal of Business \& Management, Vol.5 Issue 1, pp. 35- 42 